\title{
AN ETHNO-CULTURAL PORTRAIT OF A DIASPORA IN CENTRAL RUSSIA: THE FORMATION AND CULTURE OF THE EASTERN UDMURT
}

\author{
Eva Toulouze \\ Institut National des Langues et Civilisations Orientales, Paris, France \\ Department of Ethnology \\ University of Tartu, Estonia \\ evatoulouze@gmail.com \\ Nikolai Anisimov \\ Department of Folkloristics, Estonian Literary Museum, Estonia \\ Department of Philological Studies \\ Udmurt Institute for Research in History, Language and Literature \\ (UdmFRC UB RAS) Izhevsk, Russia \\ nikolai.anisimov@folklore.ee
}

\begin{abstract}
The Eastern Udmurt are a peripheral Udmurt ethnographic group whose members live mostly in Bashkortostan. This article introduces the reader to the migrations that led to the formation of this group, and to the main cultural characteristics that determine the originality of the Eastern Udmurt. Their settling in the Bashkir lands took place due to the penetration of the Russian power in the Volga region, which happened in the sixteenth century through warfare that damaged the local population. They started to settle in more peaceful regions, and the migration was continued in the subsequent centuries, reaching the peak with the forceful Evangelisation of the eighteenth century. This culture is rich and original: it has retained many Udmurt features as the ethnic religion that is still alive, and has merged with Turkic features in several important aspects, such as language, costume, and music. This is the first part of a study that will continue with the observation of Eastern Udmurt organisations and the relation to their core territory, nowadays the Republic of Udmurtia.
\end{abstract}

Keywords: diaspora, Eastern Udmurt, ethnic religion, ethno-cultural portrait, Finno-Ugric, migration, Turkic influences, Turkic peoples, Udmurt 


\section{INTRODUCTION}

The aim of this article is not to develop a discussion on the theoretic notion of diaspora. We start from the idea that a diaspora is an ethnic group separated from its historical core territory but feeling a connection with it, either real or imagined, and has avoided, in its new habitat, total assimilation with the core inhabitants. There may be several different origins and reasons for the formation of a diaspora. The Jews, for example, migrated because of the loss of their original territory; the Portuguese or the Poles in France, the Italians and the Turks in Germany came to work in better conditions with better wages; in other cases, the displacement is connected to education: the younger Udmurt in Estonia came to receive higher education, and more precisely, a doctoral degree.

The case this article is referring to belongs to neither of these models and is much more remote in time.

\section{THE EARLY UDMURT MIGRATIONS}

Here we will not dwell on archaeological data that prove the existence of Udmurt-speaking communities in some concrete parts of the Ural-Volga region in prehistoric times. We rather limit our reflections to the historical periods and, more precisely, to the time in which the life of the Udmurt community was disrupted by major historic events. These events were connected with the expansion of Russian statehood eastwards.

\section{Before the occupation of Kazan in 1552}

The ancestors of the contemporary Udmurt were separated into two administrative units, which determined the distinctive features of their cultures. The northernmost communities were integrated after their formation into the "Vyatka lands", which was a buffer state between Moscow and the Turkic Kazan Khanate (Grishkina 1994: 26). It was a city-state structure, under the rule of an oligarchy, where the Udmurt lived quite isolated in the eastern forests. However, they interacted with their neighbours, who were mainly Russians (Makarov 1995: 84-85). This Russian influence was even more reinforced after Moscow finally absorbed the Vyatka lands in 1489 , after several attempts that had brought the two units closer and closer (Grishkina 1994: 28-30). Thus, at the beginning of the sixteenth century, part of the Udmurt had already been brought under a much wider Russian rule than it was in the Vyatka state 
(Atamanov \& Vladykin 1993: 27). The other part of the Udmurt lived in the well-organized Turkic state of Kazan. It was one of the states born in the aftermath of the Mongolian expansion westwards in 1222, and the subsequent retreat towards Mongolia. This state bore several denominations, including the Golden Horde and, finally, the Khanate of Kazan. The Turkic state was a strong one, with administrative and financial structures, a body of civil servants, an army, and taxes. Here, the dominant cultural influence was Muslim and Turkic. Conversion to Islam had not been a policy of the Turkic state, so that the Udmurt as well as other Finno-Ugric communities had been able to practice their religious understandings undisturbed. This strong state, as well as its predecessors, was an important actor in Russian history: they had subjected the Russian principalities, which for centuries had been compelled to pay tribute to the Tatar-Mongol rulers. Thus, Moscow's expansion eastwards had two goals: give more and more living space for the population, but also gain freedom from the subordination to the Tatar rule. Moscow endeavoured to achieve its goals gradually, and succeeded within a campaign led by Ivan IV the Terrible, in 1552, to occupy the centre of the Khanate, the city of Kazan (Grishkina 1995: 111-112).

\section{The consequences of the conquest of Kazan}

Kazan was taken by warfare. Warfare is always devastating for the civil populations who suffer from the depredations of both armies. While undoubtedly locals' feelings were different as to the old and new rulers, the misery of the populations that had to feed hostile bodies of soldiers was deep. Many peasants were deprived of their livelihood and faced desperate conditions. Even the words colonisation, exploitation, depredation (Grishkina 1994: 33-35) and genocide have been used in this context (Osipov 2008: 21, Torbasov n.d.). This was certainly a huge stimulus to flight: by whole villages, the local populations fled to look for quieter life conditions elsewhere.

Thus, the first indictment to quit their core lands was the trouble brought by warfare and the collapse of the Tatar rule. The Southern Udmurt who fled looked for peace and prosperity in the areas where the Tatar rule had not been challenged - eastwards, in the Bashkir lands.

Later on other reasons emerged to continue this migration movement. While certainly it was due to a multitude of factors - the heavier and heavier tax load, compulsory work set upon villagers, etc. - their descendants had to endure particularly one of them, the religious load imposed upon them. 


\section{Evangelisation}

One of the first means to integrate the new lands into what was becoming an empire was the imposition of Orthodoxy as the religion of the sovereign. Among the first measures, as early as 1555, a bishop was appointed in Kazan (Bernshtam 1990: 138), and mosques were destroyed throughout the whole territory. Then attempts to convert the new populations started to be made. To begin with, monasteries were built, which took possession of the lands and employed the peasants whose lands they had taken (DeWeese 1980: 115). These monasteries served the spiritual needs of the newcomers but were also powerful signs of the new power's presence. Secondly, depending on the understanding of different bishops, conversion policies were - or were not - implemented. The first conversion policies encompassed both reward and punishment, offering rewards as gifts of crosses and shirts, pardon for crimes, exemption from taxation; non-Christians were not allowed to have Christian serfs, etc. (Luppov 1999 [1899]: 100). Punishments were mostly isolation from the non-baptised or heavier taxation: the taxes not paid by the newly converted were transferred onto the non-baptised population. There were some conversions among the nonRussians (Zahidullin 1997: 52). This policy, however, was neither permanent nor consequent: it was not always properly implemented and sometimes contradictions between the Church's promises and acts of the civil power disrupted the conversion attempts. At the beginning of the eighteenth century, different ukases from Peter the Great, aiming at converting indigenous peoples and eradicating paganism in the empire, as well as depriving Tatar elites of their privileges (Kappeler 1994: 41) increased the pressure. However, no actual efficient conversion policy was implemented until 1740, when the creation of an office for the newly converted took systematic measures to convert the animist population (Luppov 1999 [1899]: 141-142), who were much easier to baptise than the dogmatic Muslims. These conversions relied on a fraud or at least a misunderstanding: the animists were accustomed to tolerance toward other religious practices and could not understand Christian exclusivism. Moreover, almost no explanations were given, out of belief in the magic force of baptism. Constraint was used against those who were reluctant to let themselves be baptised (Kappeler 1982: 277; Brennan 1987: 128-129; Luppov 1999 [1899]: 148). The missionaries were accompanied by soldiers, who were threatening per se. This campaign lasted 26 years and was successful: most of the animist population were baptised, and as apostasy was criminalised, they had no possibility to undo the procedure (in spite of several attempts, especially by the Mari; see Lallukka \& Popov 2009). 
This forceful interference in the peasants' lives was very much intrusive and many were dissatisfied. While this was not the only reason for migration, in the memory of the migrants, which they transmitted to their descendants, is that they left their lands because of religious oppression, in order to live according to the rules of their ancestors.

\section{Migration}

Thus, the Udmurt - as well as the Mari, the Chuvash, and Mordvinians - fled eastwards by whole villages. They looked for lands to rent and found them in areas inhabited by Turkic peoples. Over the Kama River, on its eastern shores, there were huge extensions of land scarcely inhabited (Sadakov 1949: 13). The Bashkir were a nomadic people. The Tatar were more sedentary. But space was available and they rented it to the Udmurt, who later bought it for themselves.

Among the different hypotheses about the Udmurt settlement in Bashkortostan, the most accepted nowadays is the stance of Pavel Luppov, a scholar of Udmurt evangelisation, who identifies three stages in the migration. The first stage was in the sixteenth century, after the taking of Kazan. Actually, the first mention of an Udmurt settlement is from 1572 (Safin \& Mukhtasarova \& Khaliulina 2009: 10). The second one, according to Luppov, was in the first decades of the eighteenth century, at the time of the first revision (census) and the introduction of the capital tax. The third stage took place in the middle of the eighteenth century, and was directly connected with the forceful evangelisation implemented by the Office of the Neophytes (Sadikov 2001: 17). Often, coming from Udmurt villages in the core territory of the ethnic group, the newcomers brought along the village name, Gondyr, or the clan name - Mozhga. Detailed studies on micro-ethnonyms show that many of them came from Southern Udmurt regions in the Perm region (Chernykh 2017: 16) as well as in other regions of Bashkortostan (Sadikov 2001: 19-21), although some clan names suggest that some newcomers came from Northern Udmurtia (Nasibullin 1997: 12).

\section{THE RESULT OF THE MIGRATION: FORMATION OF THE EASTERN UDMURT GROUP}

The Eastern Udmurt group is one of the peripheral Udmurt ethnic groups. The English name Eastern Udmurt has been given to them by the authors of this article, who attempted to find a comfortable denomination. In Russian, they are usually called zakamskie udmurty (the Udmurt from over the Kama), which is 
a concrete and precise expression, but not easily translated into English. This name was first used by N.I. Tezyakov in 1892 (Sadikov 2019: 24). There are also other expressions: Bashkir ethnographer Kuzeev proposed priural'skaia territorial'naia smeshannaia vnutrietnicheskaia etnograficheskaia gruppa udmurtov (the territorial mixed intraethnic ethnographic group of Udmurt by the Urals), which is an even more uncomfortable appellation, both in English and in Russian (Kuzeev 1992: 260). He also used the simple term priural'skaia (by the Urals), but it is not much more convincing than the former (Sadikov 2001: 5). Some use the expression bashirskie udmurty, bashkir udmurt"es (the Bashkir Udmurt), as, for example, Nurieva (2013: 151), but this expression is not fully correct. It is possible to talk about the Bashkortostan Udmurt, but this expression is very precise about the Udmurt living in Bashkortostan, while the Eastern Udmurt live also in the region of Perm and Sverdlovsk oblasts.

Ethnographers divide them into several territorial subgroups. Sadikov has proposed the following division (see Fig. 1):

1. The Tanyp Udmurt, in part of the Yanaul, Kaltasy, Burayevo, Baltachevo districts (first mention in 1627; archive material 1):

a) The Tashkichi Udmurt in one village of the Il'ishevo district and one village of the Burayevo district (first mention in 1739; Davletbaev 1986: $130)$;

b) The Kanli Udmurt in one village of the Kushnarenko district (first mention in 1769; archive material 2) (Sadikov 2019: 9-11).

2. The Buy group, in part of the Yanaul district and the Kueda district of the Perm kray (first mention in 1684; Davletbaev 1986: 138) (Sadikov 2019: 11-12).

3. The Tatyshly group, with almost all the villages of the Tatyshly district and one of the Kueda district of the Perm kray (first mention in 1670; archive material 3) (Sadikov 2019: 13).

4. The Bavly group, in the Bavly district of Tatarstan and the Yermekeyevo district of Bashkortostan (first mention in 1640; archive material 4) (Sadikov 2019b: 13-14). Actually, Galina Nikitina does not include this group among the Eastern Udmurt. She just notices that some Udmurt villages are situated south in relation to the others (Nikitina 2011: 4).

5. The Krasnoufa group in the Krasnoufa district of Sverdlovsk oblast' (first mention in 1679; Chagin 1995: 46) (Sadikov 2019b: 14-16), which is practically extinct or on the verge of extinction.

6. The Knyaz'-Elga group of Il'ishevo district in Bashkortostan (Sadikov 2019b: 16). 


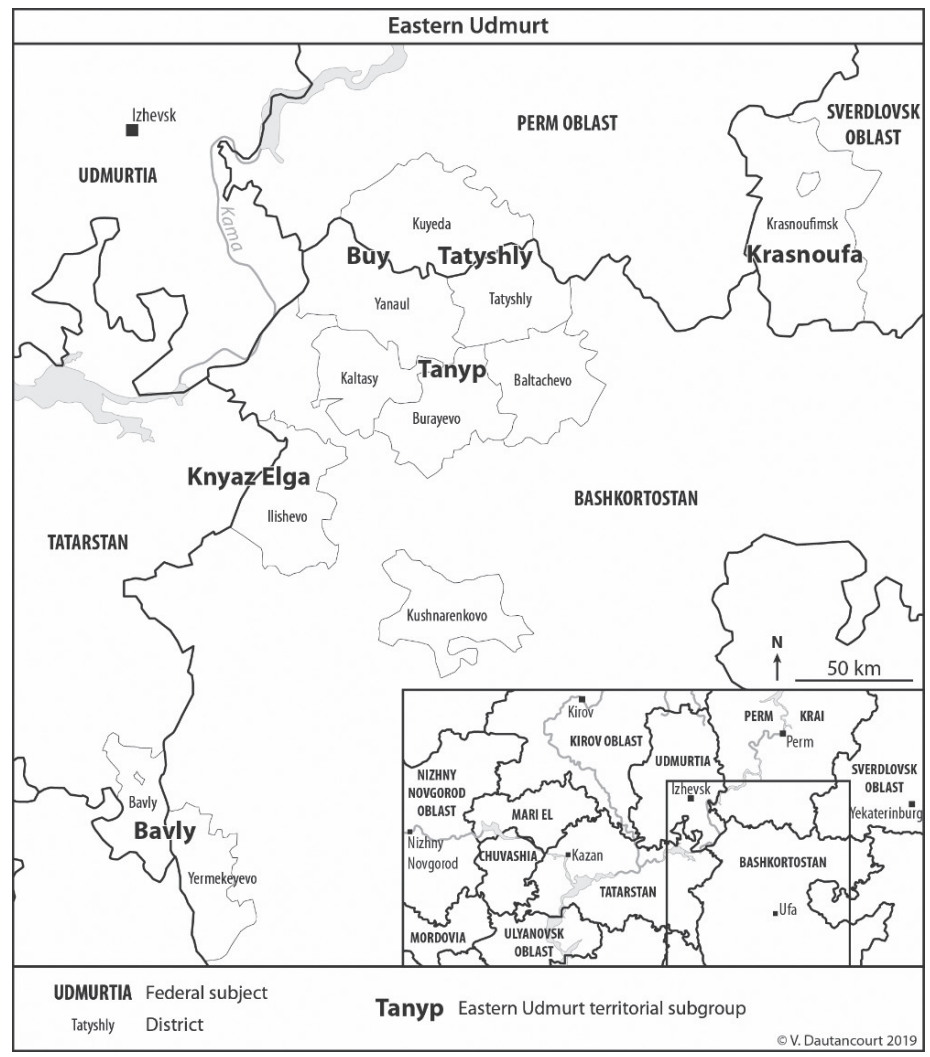

Figure 1. Map of the territories inhabited by the Eastern Udmurt. Vincent Dautancourt 2019.

Today these groups do not represent a homogeneous cultural whole. There are discussions on the belonging of the Bavly Udmurt to this group. While the origin of this group is not under discussion - migrations from an original habitat under the pressure of historical events - the time of this migration is arguable: either the seventeenth-eighteenth centuries (Pesni 2018) or the mid-sixteenth century (Valey Kel'makov, personal communication 2019). As the differences in several fields of culture are remarkable (musical tradition, dialect, traditional worldview, etc.) as our expedition in July 2019 revealed, we do not attempt to unknot the problem here, but we have not included the Bavly Udmurt in our reflexions.

The archives reveal some interesting facts:

1. As the abovementioned data show, different villages are first mentioned on different dates and in different periods of time. This confirms that until the nineteenth century there had been not one migration wave but several. 
2. Several villages established as Udmurt were assimilated by the local Turkic and Muslim - population. They became Tatar and converted to Islam, in some cases also losing the original Udmurt language; until today the villagers have retained a memory of once being Udmurt (for example, Garibash in the Tatyshly district of Bashkortostan; for more details see Sadikov 2019a).

3. They also give witness to internal migrations, with part of the population from one village separating from the original village at some moment and settling in a new one. The new village may be either close to the "mother village", as in the case of Novye Tatyshly (mother-village) and Maysk - at the distance of three kilometres, or Urazgildy and Vyazovka (nine kilometres) or farther away, as in the case of Starokalmiyarovo (mother-village in the Tatyshly district) and Kalmiyar (Kueda district of the Perm kray). These origins are well remembered by villagers and are clearly retained in the religious life of both villages: Maysk and Novye Tatyshly hold their village ceremonies together, just like Starokalmiyarovo and Kalmiyar, in spite of the distance and the separation that took place in the mid-nineteenth century (Chernykh 2017: 18) have done for decades. The relations between Maysk and Novye Tatyshly, which are at the distance of four kilometres from each other, are fully alive. But it has now been some decades that the relations between Starokalmiyarovo and Kalmiyar have faded; the two villages are several dozens of kilometres apart and in two different administrative units.

These groups have retained some general features of their common origins and new life conditions, which distinguish them from the Udmurt that remained in the core territory.

This population is now around 20,000. The historical data reveal the following evolution:

$1725-3,294$

$1795-6,912$

$1834-11,770$ (in the Orenburg governorate)

$1897-22,501$

$1926-23,256(95.8 \%)$

$1979-25,906(93.3 \%)$

$1989-23,696(90 \%)$

$2002-22,625$

$2010-21,477(89.5 \%)^{1}$

This overview (Safin \& Mukhtasarova \& Khaliulina 2019: 660-661) shows that by the eve of the revolution, the Udmurt in Bashkortostan had reached more 
or less the number we witness today and that until today their overwhelming majority has acknowledged Udmurt as their mother tongue, which is considerably more than in Udmurtia (65\%). The demographic data show a slight decrease in the last decades, while the population still remains around 20,000.

One characteristic of this population is its rurality. The Udmurt in general do not live in towns, and when they do, they do not settle very far from their native regions: while only $0.1 \%$ live in the Bashkir capital Ufa, $9 \%$ live in Yanaul, and only 1.3\% in Neftekamsk (ibid.: 663). But these statistics take into account only Bashkortostan, while the towns to which mostly the Udmurt from Bashkortostan migrate are not in the republic, but close to it, in the surrounding regions - Udmurtia and Perm kray (Chaykovski, Chernushka). The rural character is certainly one of the important elements of the overall stability in this area.

\section{DISTINCTIVE FEATURES OF THE EASTERN UDMURT}

In general the Eastern Udmurt are characterised by a strong influence of the environing Turkic culture. This influence manifests itself through both resilience to other influences and elements of active borrowing in different domains.

\section{Resilience to Russian influences}

In other parts of Russia, the Udmurt have been subjected to the strong influence from the Russian presence. It is manifested in the way they assess themselves as well as in the religious field.

\section{Self-dignity}

In the places in which Russian culture has been dominant, the colonial rule has led to a clear attack on the dignity of the indigenous peoples: they have been seen as inferior and have been convinced of their own indignity by permanent pressure (Grishkina 1994: 43). Even communities much more developed than the Russian ones have been seen in this way: as Miropiev (1908) observed, Russians, even at the beginning of the twentieth century, thought that they had brought culture and modernity to the Estonians, while the Estonian communities, thanks to Protestantism, had been massively literate since the beginning of the nineteenth century. Data about the way the Udmurt were seen by the coloniser are not difficult to identify both in literature (Dido 1902) and in 
fieldwork ("we are a second category people", said the Udmurt in Udmurtia at the end of the twentieth century). They had also interiorised the views of the coloniser on beauty, underestimating their own arguments according to other canons (Nikitina 2015). They also started to abandon huge fields of language use to the domination of Russians, and showed reluctance to use it in public, as this use was stigmatised by a part of the population, both Udmurt and nonUdmurt. The fact that Izhevsk, the capital, was and still is a Russian town did nothing to soften the aggression against the Udmurt. This was further enhanced by the repressions that lasted for the whole decade of the 1930s and continued far into the 1940s, and in which the ethnic factor was predominant (Toulouze 2017). The first to suffer from it were the intellectuals. The de-Stalinisation process in the late 1950s and through the 1960s found an Udmurt population tongue-tied by terror and self-loathing. This is no more the case, of course, especially with younger generations born in the late Soviet period and beyond, but the legacy cannot easily be forgotten.

Nothing of that happened with the Eastern Udmurt. Safin and his colleagues emphasised that the Udmurt were not looked down on by the locals, especially after they had participated in the latter's struggle against the tsarist rule: "unlike the groups that were surrounded by Russians, who looked down on the 'natives' as second rank persons, the Southern Udmurt who were surrounded by the Bashkir did not consider themselves as such" (Safin \& Mukhtasarova \& Khaliulina 2009: 11-12). This does not mean that, as some informants told us, the Tatar did not use despising expressions toward the Udmurt, but one informant recognises that "things are better now". Moreover, the Udmurt argue that they are a hardworking people, and this is confirmed, as a stereotype, both by the Tatar ${ }^{2}$ and by Russians (ibid.: 19). This enhances their dignity in their own and in others' eyes.

As for later periods, the relative importance of the intelligentsia was minimal; most of the Eastern Udmurt were peasants living in villages. Moreover, the percentage of Russians in these areas is also minimal and far from dominant. The dominant ethnic group here are the Tatar. While being quite similar to Russians in the superiority feeling towards others, the manifestations are quite different in everyday life: they rather ignore the others than humiliate them. So the Eastern Udmurt are proud of their Udmurtness and feel much more confident than their counterparts in Udmurtia. They have retained their language considerably better and they are not ashamed to use it in any environment. This is not supported by any particularly resilient ideology, but just by practice and the wish to live comfortably within the space created by one's mother tongue. 


\section{A distinctive religious practice}

According to Nikitina, the main characteristic feature of the Eastern Udmurt is their traditional, non-Christian religion (Nikitina 2011: 4). They fled, as some scholars emphasise, less from Christianity itself rather than from the methods of its propagation (Safin \& Mukhtasarova \& Khaliulina 2009: 19). Indeed, allegedly, forceful evangelisation was the main reason for migration. The refugees wanted to continue living according to their traditions and were hindered by the aggressive policy of forceful evangelisation.

In the Turkic territory, they were shielded against these endeavours by the explicit hostility to it by the Moslem population. The latter did not allow missionaries to reach the Udmurt villages. Even scholars had to suffer from this hostility; for example, Hungarian linguist Bernát Munkácsi could not gather materials in the Eastern Udmurt villages at the end of the nineteenth century, as he was suspected of being a missionary (Sadikov \& Minniyakhmetova 2012: 52).

So Christianity, while in Udmurtia it obliged the Udmurt to follow its rules, was totally absent from the Eastern Udmurt areas. Not so, though, Islam. Islam was pervading in these regions as the dominant religion. While the Islamisation policy was not as systematic as Evangelisation, it had the basic advantage of not being state-ruled. The Islamisation process went on and on steadily, and was particularly intensive in the first years of the twentieth century (Nikitina 2011: 6). So, some Udmurt villages decided to integrate into their new environment as a whole and adopted both Islam and the Tatar culture along with the Tatar language (cf. above). But most of the villages remained as they were, which means that they pursued the religious practice that characterised them "at home". This manifold practice, with collective clan and family levels, with a pervasive presence of the dead, and both familiar and non-familiar universes filled with spirits, has subsided by today. So, the Eastern Udmurt are characterised by what they themselves call "paganism", which means they have their own religion, which is different from the surrounding world religions based on dogma.

Of course, it has not remained unchanged for centuries. Firstly and above all, it has evolved according to its internal rules - some dimensions have faded, others have been introduced. Secondly, the general environment has influenced these processes greatly: after 1917, like everywhere else in Russia, the Soviet rule implemented its anti-religious policies here as well. But because of several aspects their effects on the Eastern Udmurt were slower and more limited than elsewhere: first of all, there was no centralised hierarchy to attack; the sacrificial priests did not differ from any other village-dweller; in this region, Islam and even Christianity were primarily attacked and vernacular religious practice could somehow be ignored. Strong personalities kept religious practices alive. As it was merged with identity feelings, it was able to survive. But the overall 
atmosphere did not leave the population untouched: such institutions as school, army, and collective production units instructed the young in anti-religious feelings and materialistic ideology. While private cults could be preserved, public ceremonies often took place on working days, excluding the younger population from this practice.

All this demanded also adaptation: the bigger animals - cows, horses - were a collective property, and their sacrifice was considered as production sabotage. So sacrificial practice focused more on ewes and birds, which could be personal property. The older sacrificial places were too provocatively visible - new, more discreet ones started to be looked for (Toulouze \& Vallikivi 2016). The different personalities of sacrificial priests and party leaders played an unpredictable role, leading to a quite differentiated religious landscape at the end of the twentieth century: in some places, absolute continuity was granted, in others collective ceremonies disappeared throughout the twentieth century.

In the late 1980 s and particularly in the 1990 s a process started that is still ongoing: everywhere, revitalisation signs led to the strengthening of Udmurt religious practices, or even the restarting of collective ceremonies. The impulse for this development apparently came from local leaders, but it answered a need in the population, which is clearly manifested in the reactions to new openings (see Toulouze 2016).

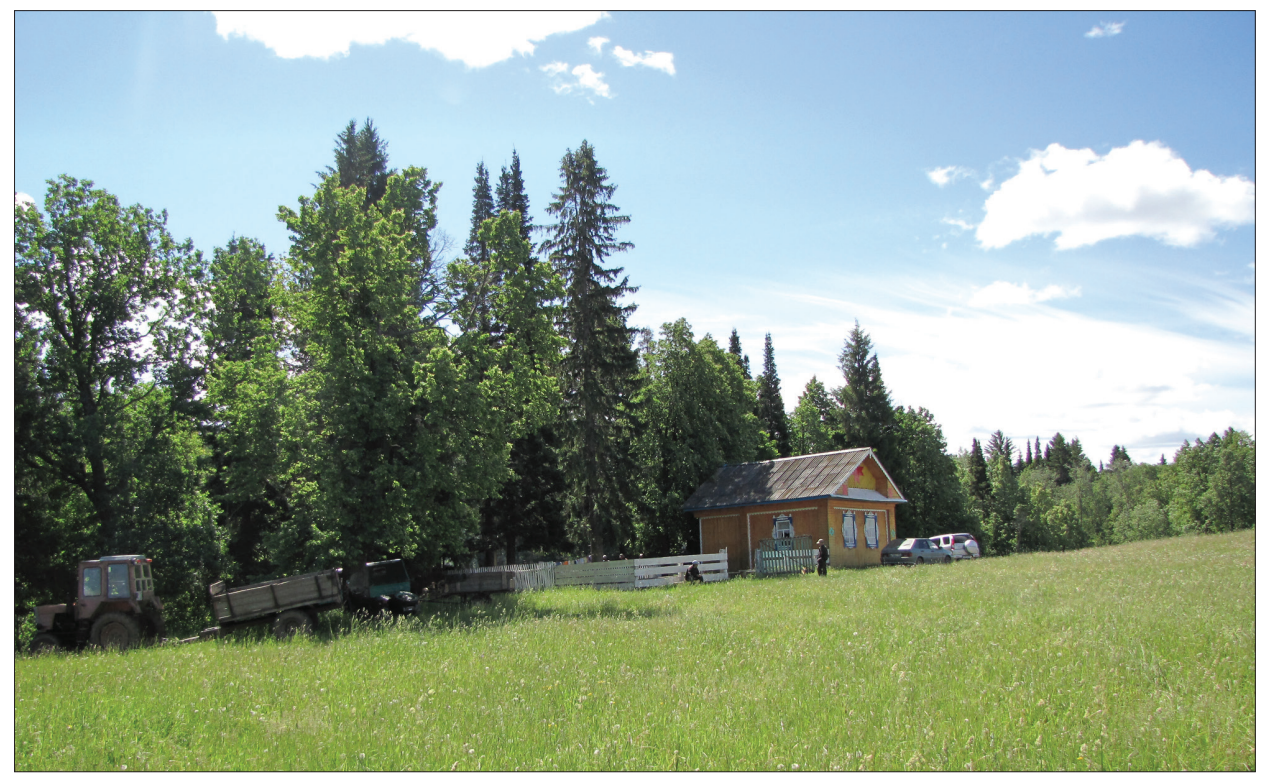

Figure 2. A sacred place in Alga (Tatyshly district, Bashkiria), with a house and a fence. Photograph by Eva Toulouze, June 2013. 


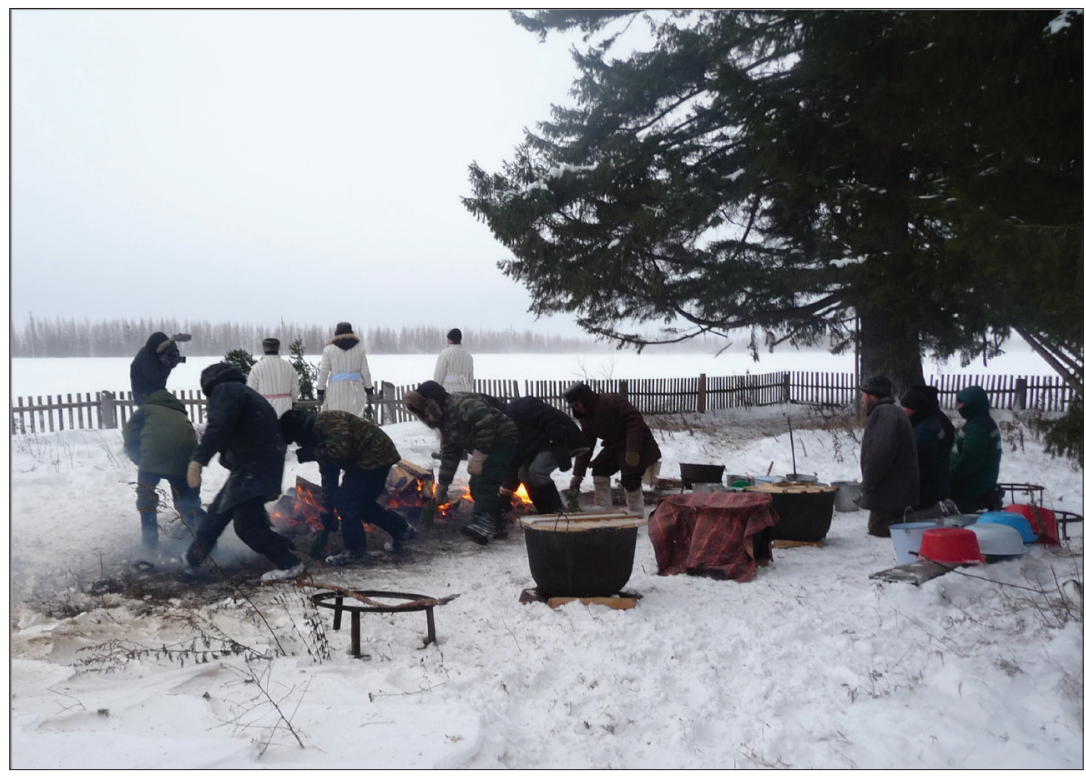

Figure 3. Ceremony Bagysh vös' between Staryi Kyzyl-Yar and Nizhnebaltachevo (Tatyshly district, Bashkiria). Photograph by Eva Toulouze, December 2013.

The first sign, at the very end of the Soviet period, was building prayer houses in the sacred sites used for collective ceremonies that had never been discontinued, on the initiative of the collective farms, and fencing or re-fencing sites. In other cases, where ceremonies had not been held for years or for decades, local leaders looked for potential sacrificial priests mostly among the descendants of former priests and encouraged them to revitalise collective ceremonies. They provided material help - i.e., found ewes for the sacrifice and helped with transportation. In some villages, as Kassiyarovo in the Burayevo district, the population put pressure on the potential sacrificial priest to organise a ceremony: he had been chosen by the previous one before the latter's demise and had never taken over the legacy. After a couple of decades, he was asked to perform and he was willing to do so, also because of unhappy incidents in his family that could have been due to his unwillingness to fulfil his promise (personal communication by Ranus Sadikov in 2015).

Another example of the willingness of the population is the attendance at existing ceremonies. In the Tatyshly district, in which a whole cycle of ceremonies existed, the intermediate ceremony between the village one and the one with nine or ten villages has either disappeared or has been inflated: originally it concerned only some villages. But today, in one of the subgroups, it brings together almost all of them - eight villages out of nine. The village in the group 
which does not participate, Kalmiyar, compensates it through the revival of its winter village ceremony. So there is a real interest and wish at grassroots level to have collective ceremonies for the community.

One reason is probably the absence of occasions to do things together at the village level. In the Soviet time, the kolkhoz organised many collective work sessions accompanied by recreational activities. Then the collective units started to have problems. For example, the "kolkhoz" Demen, covering the villages of Novye Tatyshly, Bal'zyuga, Urazgil'dy and Maysk, even discontinued the Sabantuy, the traditional feast for the end of the spring field works, which for some years was held at other levels (district, some villages) but no more at the kolkhoz level (some villages together). Such was the situation when we arrived in the field in 2013. Since then the cooperative has renewed this tradition. Knowing the low level of salaries in the cooperative, we asked the villagers whether they would not have preferred to have an increase in their wages instead, but the answer or, more precisely, the non-understanding of our question was unanimous. They all had missed this occasion to be together and rejoice, and were happy to have it restored.

It would be narrow to limit religious practice to the visible dimension of collective ceremonies: every family has its calendar practices (the great day, the

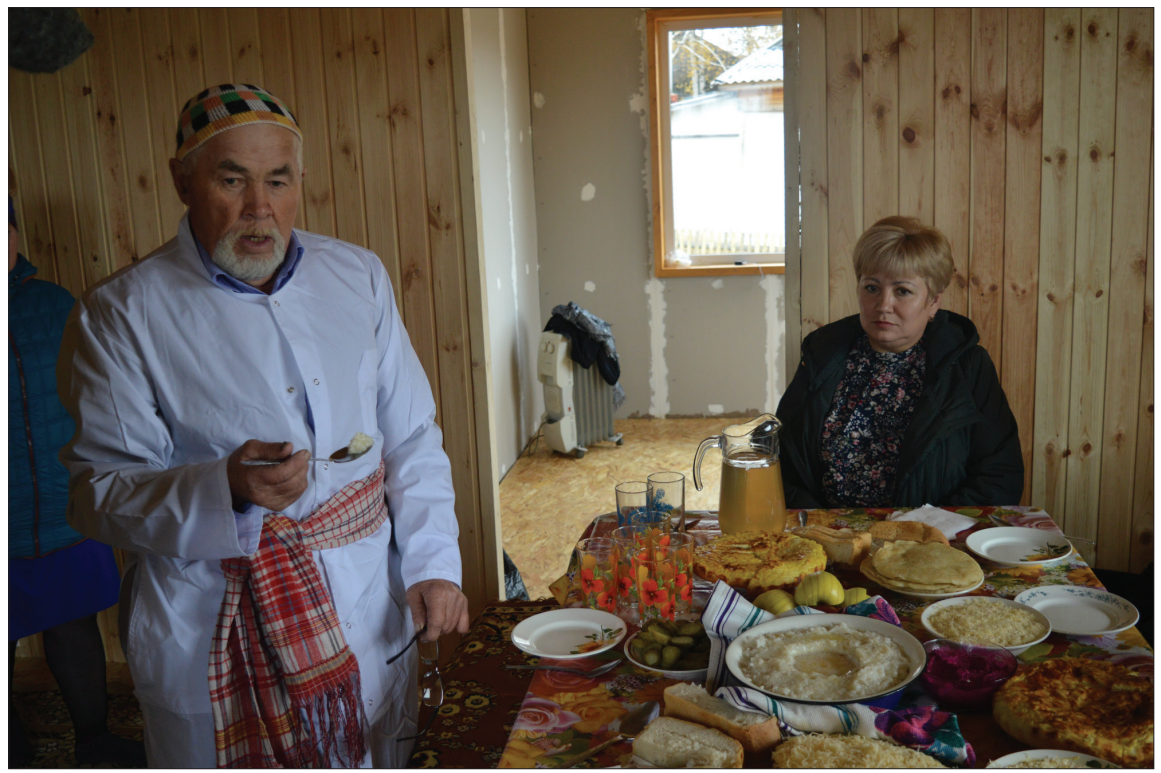

Figure 4. Ceremony for entering a new house in Aribash (Tatyshly district). The sacrificial priest eats the consecrated porridge while praying. Photograph by Nikolai Anisimov, October 2017. 
autumn ceremony, the spring and autumn commemorations) as well as their personal or private ceremonies; for example, commemorations of their dead, moving to a new house, not to speak about births or marriages. But here we shall not focus on them, because they exist, more or less, in the whole of the Udmurt territory, and they are not specific to this group. Even within the framework of Orthodoxy, many of them are still alive elsewhere. But there are only two villages by the Southern Udmurt, one in Udmurtia, Kuzebaevo, and the other not far, but in Tatarstan - Varkled-Bodya - where collective ceremonies are still held. So we may safely argue that this movement is a peculiarity of the Eastern Udmurt.

\section{Turkic influence}

This is the second characteristic feature mentioned by Nikitina (2011: 6). There are fields in which the contact with the neighbours has not protected Udmurt features but changed them, through intense Turkic influence, and this is a visible feature that may easily be identified. We shall focus here on three fields: language, music, and dress as well as ornaments.

\section{Language}

The Udmurt language has been divided into dialects since the beginning of its investigation and researchers have classified the dialects in different ways (Atamanov-Egrapi 2017 [2010]: 340-342). We will follow Valey Kel'makov's last partition, the third one he proposed, according to which the Eastern Udmurt speak a peripheral dialect of the Southern Udmurt, with four sub-dialects (Kel'makov 1998: 42). While it is distinctively Udmurt, with many common features with other Udmurt dialects, inter-comprehension with speakers of other dialects is not granted. Many features make the spoken language obscure for the non-initiated: many consonants are not pronounced or are pronounced differently: the word 'tomorrow' is, in literary Udmurt, ӥyказе, pronouced chukaz'e. In Easter Udmurt it becomes shukae, which is not easily identified in current quick speech. There are Turkic influences also in pronunciation. Mostly what may trouble speakers of other dialects are lexical items which are either nonexistent in standard Udmurt or mean something else. These may be either archaisms, which have disappeared from use in other dialects and do not exist in the literary language, or Turkisms.

Some examples of archaic forms are proposed by Irina Nurieva with words such as uнос (inos, 'good mood'; lit. 'heaven's gates'), or apm (art, 'crown of a log 
cabin'), or old female names as Чужин (chuzhin, 'yellow' + suffix in), Сяськан (S'yas'kan, 'flower' + suffix n (Nurieva 2013: 151)).

Some very common words, such as, for example, 'thank you', in standard Udmurt may (pronounced tau), are said according to the Tatar word rahmet, although it is not rare to hear "rahmet, tau, spasibo". The word for 'good' is also a Tatar loan - aybet. Tatar loans present in other dialects are used here with a meaning much closer to the Tatar original: tugan is in Udmurtia 'beloved, lover', while to the east of the Kama River it means 'kin'. 'Apple' is in Northern Udmurt, like in Russian, jablok. In Southern Udmurt, as well as in the literary form of the language, the Turkic word ulmo is also used. Actually many elderly people speak Tatar and switch easily from one language to the other. Some even argue that they speak Bashkir. This is not the case anymore with the younger, even the generation of the 45-year-olds, who have learned mostly Russian at school and are even more skilled in this language than in Udmurt.

\section{Music}

Usually the Udmurtia Udmurt say that the Eastern Udmurt have neither music nor songs of their own, and that they like to listen to and sing only Tatar songs. Indeed, according to Nurieva, all their songs are constructed according to the pentatonic system that characterises Tatar songs (2013: 151). The Eastern Udmurt have taken from Tatar tradition both the melismatic way of singing the tunes and the performance concept of myn, which expresses the masterly skill of the performer. They use in Udmurt the expression мәнль кърӟась (m“ynl kyrdz'has'), a 'skilful singer', who is a recognised and respected member of the community (ibid.: 151-152).

What seems to be true indeed is that the predominance of the Tatar style has led to the disappearance of many Udmurt songs that did not correspond to this pattern, especially the most conservative ritual songs, which were still in use in the 1970s, when Gábor Bereczki and László Vikár visited this area and recorded singing folklore (Nurieva 2013: 152). Nurieva emphasises also the gender division of some ritual songs, which is, according to her, a unique example in the Udmurt territory.

But the accusation of recognising only Tatar songs is both true and unfair. Undoubtedly, Tatar music is very popular. Grandmothers sing Tatar hits in Tatar with the greatest pleasure; "Uftanma" (Do not regret) by Elvin Grey is much beloved: we heard it sung at Kassiyarovo village Sabantuy in 2018 as well as at a private party by elderly women in April 2019. Some songs by Rishat Tukhvatullin, such as "Sandugach" (The nightingale), have even several Udmurt versions. 
As in other Udmurt communities, there are singing families and less singing families. Still, the Udmurt sing a great deal and this is true also here. Around the table, moonshine usually accompanies songs. These may be Udmurt traditional songs, which often have parallels in the Udmurt tradition in Udmurtia, with a tune that may differ.

It is true that Tatar songs are popular, but we must recognize that many of them have become Udmurt ones: they have Udmurt texts and they are sung in an Udmurt way. So we would like to emphasise that although the origin of these songs is undoubtedly Tatar for many of them, they have been assimilated and are received and performed by the Udmurt as their own. However, in the performance, comparing with the Tatar, most of the Tatar pathos disappears and is replaced by a quieter interpretation.

\section{Costumes and jewellery}

The costume of the Eastern Udmurt is considered as a variation of the Southern Udmurt one (see Atamanov-Egrapi 2017 [2010]: 218). Also in costumes and ornaments the Turkic, particularly Bashkir, influence can be observed. The Bashkortostan Udmurt costume is very colourful, in rich velvet colours. Velvet is one of the most popular fabrics used. The colours are deep green, violet, deep blue, deep red, and purple. There may also be yellow, but it is not one of the fundamental colours. They are recognizable from afar. Costumes are described in detail in some books: Serafima Lebedeva's monograph about costume, with many photographs (2008: 132-140) as well as in Irina Kosareva's book about peripheral costume traditions (2000: 162-196).

There are two main characteristics of the costume to be emphasised: the first is a flounce around the waist, meant to protect women's most vulnerable parts from external negative influences. This is an addition to the Udmurt costume which is unknown in Udmurtia. A similar flounce is also added, invisibly, to the skirt.

The other piece of clothing very characteristic of the Eastern Udmurt is a loan from the Bashkir costume, which has been fully integrated into the Udmurt costume: it is a longer vest without sleeves, usually in velvet, which is worn on the dress. It is decorated with silver or golden ribbons running along the rims. Usually the colour differs from that of the dress.

Attention usually concentrates on the female costume, for, on the one hand, the male costume was much more modest and not so spectacular, and, on the other hand, it has not made it to the twenty-first century. While women use the traditional costume quite widely, especially for festive purposes, men do not use traditional clothes at all and wear industrial clothing, whereas the traditional 
costume was made from homespun material. There is one exception: the ritual dress for ceremonies. We shall just concentrate on this topic and must go back in time for a while.
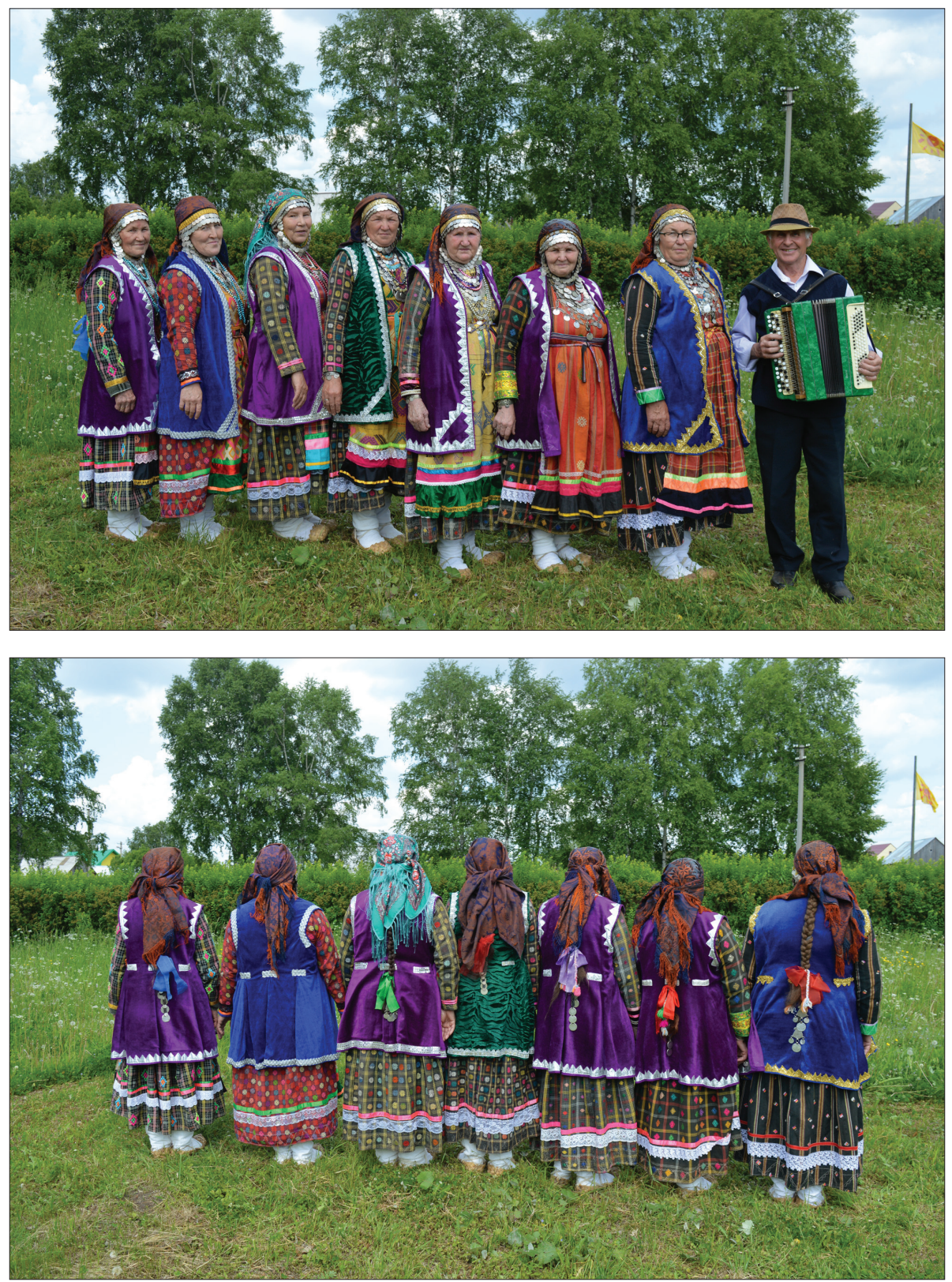

Figures 5 \& 6. The Staryi Kyzyl-Yar folk music ensemble Mardzhan (Pearl) (Tatyshly district, Bashkiria) in local folk costumes. Photograph by Nikolai Anisimov, June 2019. 
Sacrificial priests wore, as did all the population (according to old photographs), special garments for ceremonies: the ritual dress was a long handwoven chemise, white with thin vertical stripes, and white headgear on their head. The ritual dress was called shortderem and there were male and female cuts of it. The shortderem was also a mortuary costume, so during Soviet times, while no new shortderems were woven, and none were of course produced industrially, they almost disappeared - were literally brought to the grave by their owners. At the beginning of the twenty-first century only some sacrificial priests had their own shortderem. In order to perform at ceremonies, the priests had to adapt. They chose to wear white medical smocks, an industrial piece of clothing easy to buy in professional shops.

This solution was neither solemn nor particularly aesthetic, but it achieved the main goal: to be dressed in white, in order to address the white god. At the beginning of the second decade of the twenty-first century, some sacrificial priests tried to find some other solutions to give their position the desired solemnity. In the Tatyshly district, the priests of the northernmost nine villages have ordered through the cooperative industry some dozens of smocks made of a white fabric with wide vertical stripes, which roughly reminds of a shortderem.

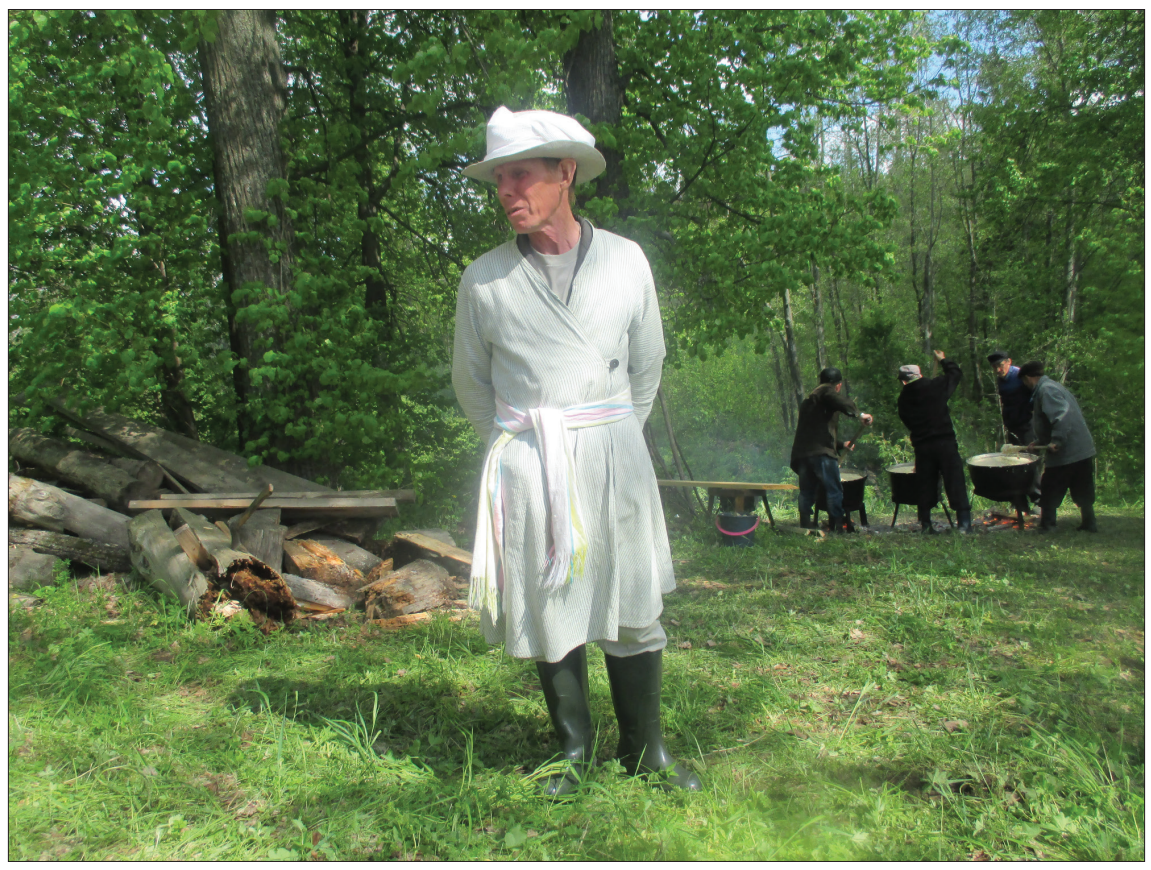

Figure 7. The sacrificial priest of the village of Vyazovka (Tatyshly district, Bashkiria) in his old shortderem. Photograph by Eva Toulouze, June 2017. 
In other districts, they have decorated their white medical smocks with Udmurt patterns, usually red, but other colours may be used as well. At the meeting of the sacrificial priests in January 2019, ethnographer Ranus Sadikov recalled the tradition and encouraged the priests to use new shortderems. Further fieldwork will show how they react.

Ritual costumes for females were also called shortderems. Some elderly ladies still have theirs and attend ceremonies dressed in them. But it will probably be used as a mortuary dress and will go to the grave with them. While the sacrificial priests have been trying to follow some aspects of tradition or to revive them, the attendants do not endeavour to follow the old prescriptions. Very few come in white or lighter colours. Usually women mark the solemn character of the ceremony by wearing folk costumes, and not even all of them. In the past six years, we have seen a decrease in the use of the folk costume at ceremonies.

Similar to Udmurtia, the Udmurt female costume includes plenty of silver. Silver in general is believed to have a protective function and so it is here. Longer or shorter ornaments covering the chest are used; they are made of silver coins and are passed on from mother to daughter or to daughter-in-law, if the families were wealthy enough to have them. Their function, besides the decorative aspect, was not only to emphasise wealth, but to grant the bearer protection from the evil eye: the coins attracted attention and distracted it from what was below. The clinking of metal also had the function of keeping away evil spirits. We use a past tense because although these functions are not totally ignored nowadays, it is not the principal inducement to use them.

What has been presented in the former paragraph is true for the whole of the Udmurt territory. But there are peculiar features by the Eastern Udmurt: the taste for silver is much more implemented here than elsewhere. Besides the chest ornaments, silver ones surround the face: on the brow, a row of silver coins is sewn to a light cap to be worn under the compulsory headscarf. Another row of coins is fixed to the ears and hangs under the chin like a peculiar beard (for some details and the names of the ornaments see Lebedeva 2008: 140-141).

The elder Udmurt women plait their hair, which cannot be seen under the compulsory headscarf. Still their long plaits are visible on the back, and are also decorated with older silver ornaments, often enhanced with coins and orange stones. This kind of jewellery was very popular among the Tatar, as can be seen in Kazan. Nowadays they are rare, for the production has been discontinued.

In the overall impression left by the Eastern Udmurt culture, we can recognise the Tatar taste for colour and brilliance. 


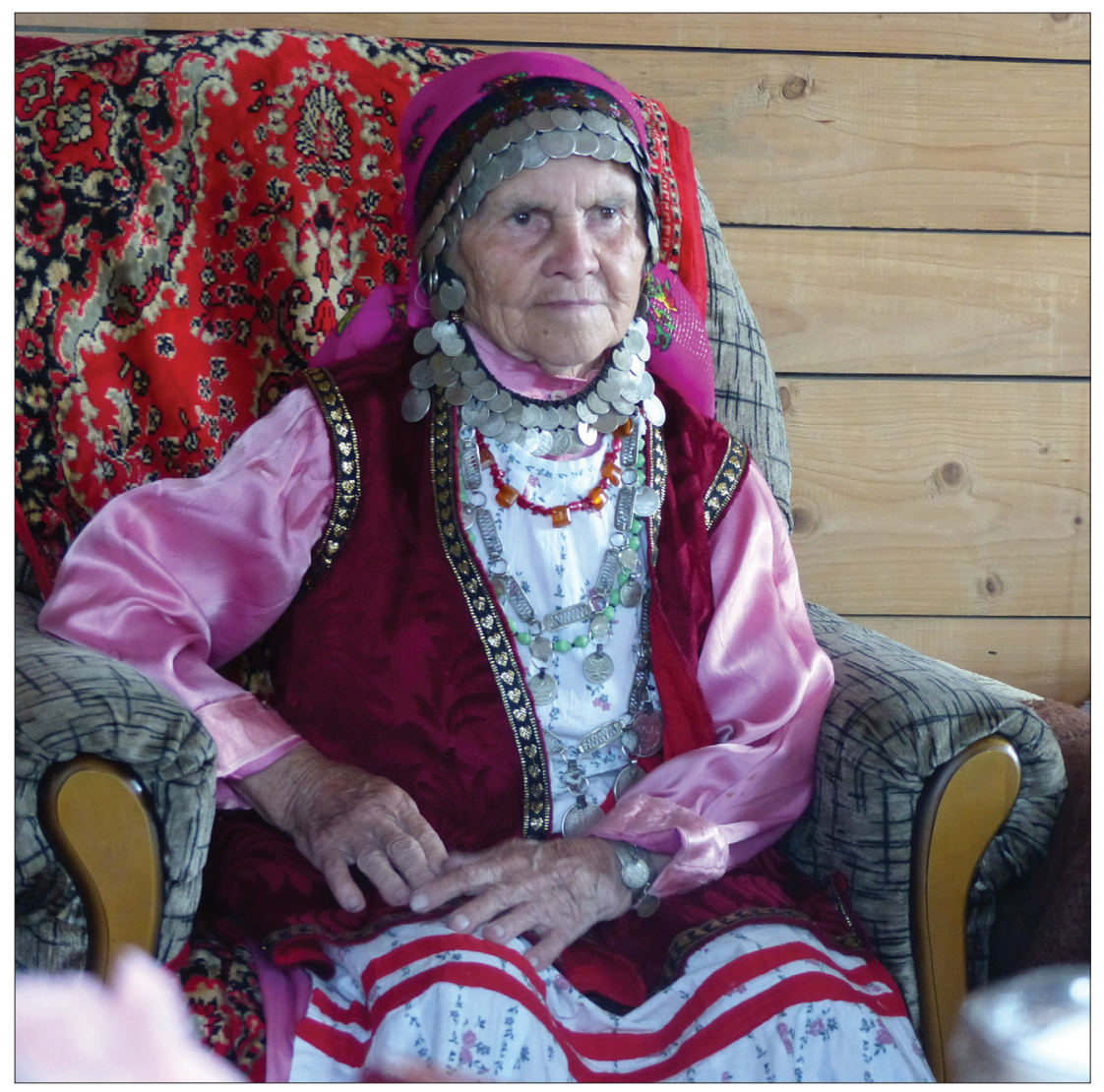

Figure 8. Anfisa Baimieva (Nizhnebaltachevo, Tatyshly district, Bashkiria), wearing her silver ornaments. Photograph by Eva Toulouze, June 2016.

\section{IN CONCLUSION: SOME CONCERNS AND NEW MIGRATIONS}

Indeed, the "purest" of the Udmurt have so far managed to maintain their resilience and the Udmurt language is very much alive, despite the general trend of Russification. The Turkic shield used to be efficient, but is it sufficient to face the contemporary challenges?

The Eastern Udmurt have benefitted from favourable circumstances. Prosperity in agriculture, an ethnically not too pervasive environment, allowed them to retain what they received in their families - language, religion, habits. This was not supported by any external ideology: they did not speak Udmurt at home because they wanted to preserve their mother tongue, but just because it was their mother tongue and it was natural to speak it.

However, the circumstances have changed in the last decade. 


\section{Agricultural prosperity}

This expression refers to the past. The time of successful kolkhozes is over. The fate of Demen is a very convincing illustration. Already in 2013, the director, Rinat Gallyamshin's son Rustam, complained that the younger villagers were not keen to work in the enterprise. His explanation was quite simple, but not entirely convincing: "They all want to sit at their computers or behind their smartphones and spend all their time on social media" (personal communication, June 2013). While undoubtedly this global phenomenon is quite characteristic of young people in Russia as well as in other parts of the world, it does not explain everything.

The salaries in the enterprise were very low. While the older population, without any alternatives, accepted it, the younger ones were no more interested in demanding physical work for salaries which did not allow them independence. Already in 2013, Demen had ceased to be the main employer in the four villages mentioned above. In the following years, the enterprise was bought by several investors in succession, Rustam found another job, and Demen struggles to have

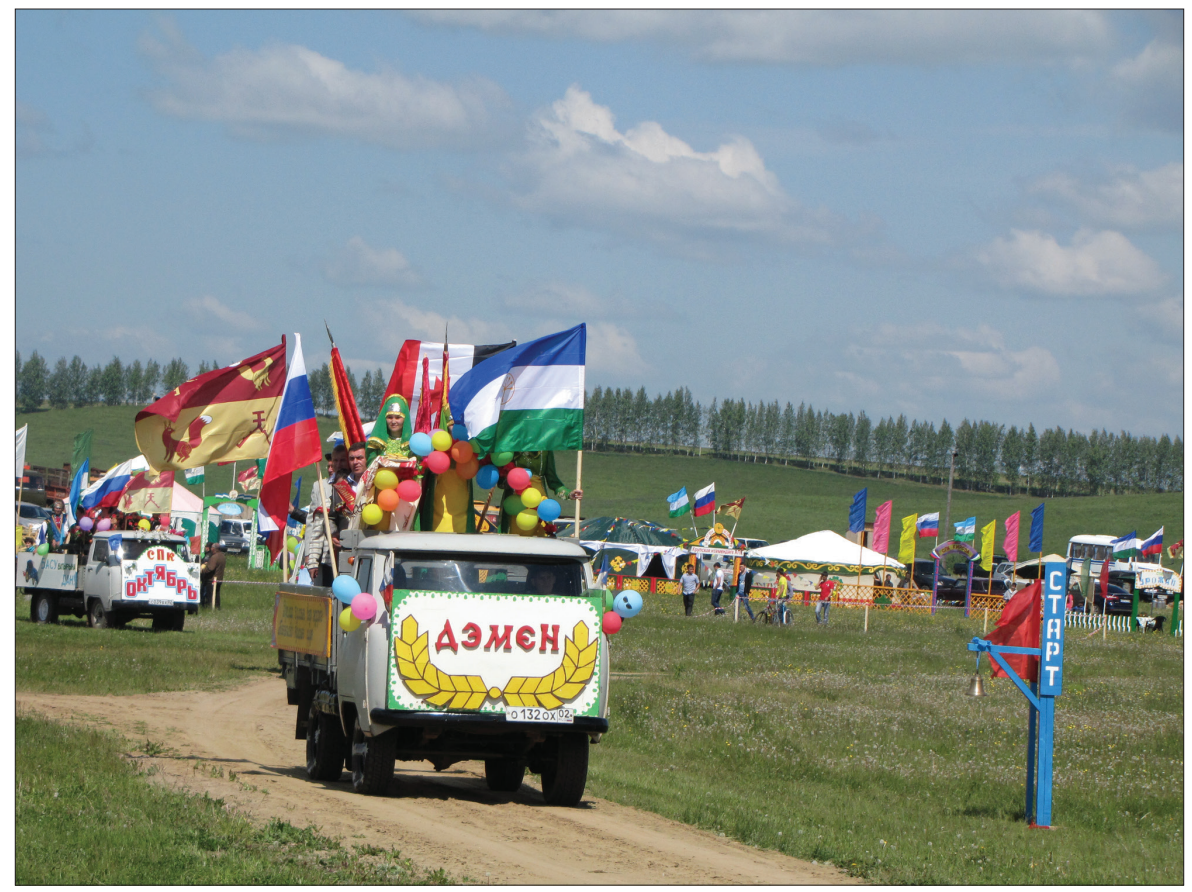

Figure 9. Festive truck of the cooperative Demen at the June 2013 district Sabantuy (festival at the end of the spring field works, Verkhnie Tatyshly, Tatyshly district, Bashkiria). Photograph by Eva Toulouze. 
good agricultural results. The village provides no jobs allowing young people to get married and to support their families. Higher wages are to be found elsewhere. The closest and furthest towns and the metropolis offer manifold opportunities both for specialists and for simple workers, and young people are keen to take advantage of this.

They are also willing to change their way of life. Life in villages has its own rules: people simultaneously have a profession and practice horticulture and animal breeding. This puts an enormous burden on men and women alike. Not only is one's potential leisure time occupied with compulsory work with crops and animals, but one is not allowed vacations, for tending domestic animals requires permanent presence. Moreover, the village environment provides sufficient infrastructure neither for everyday life nor for entertainment. Roads are of poor quality and movement is often hindered by mud. Sources of entertainment are scarce and do not vary considerably. Unlike their parents, the younger generations are not satisfied with disco evenings in the local club anymore. Communications are also not comfortable. Mobile network does not reach all villages and nor does access to the internet, which are of vital importance for the younger generation. With employment in town, people enjoy more freedom and younger generations are willing to switch to this way of life.

\section{New environments}

Thus younger people are quitting village life. They go to live in closer or fartheraway towns, in which Udmurt diasporas reside, even if of different origins. The closest towns are in the Perm kray (Chernushka, Chaykovski), in Bashkiria (Neftekamsk, Yanaul) or in Udmurtia. Chernushka hosts mostly the Udmurt coming from Bashkortostan (2,360 in 2010), while in Chaykovski the Udmurt come mostly from Southern and Central Udmurtia (see Chernykh 2017: 18). Further towns also host Udmurt diasporas: for the Tatarstan Udmurt, Kazan is an attractive destination; for the Udmurt from Bashkortostan it is the Bashkir capital Ufa, but also Perm (for the Udmurt recently mostly coming from Northern Udmurtia; see Chernykh 2017: 17-25) or Ekaterinburg, with a strong community, not to talk about Moscow or Saint Petersburg. What characterises all of these places is their dominant Russian culture.

While at home Udmurt was not challenged as a communication language, in their new environment Udmurt is virtually non-existent. They may keep to it at home, among spouses, but it is not shared outside the family. Everything is in Russian: children brought up in this context will definitely not have Udmurt as the language of social communication; moreover, parents automatically switch to Russian while intercommunicating with their children. They endeavour to 
make life simpler for the next generation, thinking of the commercially nonexistent value of Udmurt and of the need of good Russian at school. They see their non-Russian mother tongue as a hindrance and they are not aware of the danger of depriving their children of bilingualism. The grandmothers and grandfathers are thus compelled to resort to Russian in order to communicate with their grandchildren.

As no ideology contributed to the good preservation of Udmurt in the past decades, there is no ideology there to save it today. In Udmurtia, there is a starting point, with younger intelligentsia endeavouring to revitalise the language use. But in peripheral regions nothing of the sort is being implemented.

Today we have witnessed several examples of adults coming back home for the Udmurt ceremonies, even if lack of practice may hinder them to speak the language actively. Thus in 2019 we met, at a ceremony in Kaymashabash (Yanaul district), an assistant to the sacrificial priest, who is a young physician (around 35) who settled in Krasnodar long ago, married a Russian lady and does not feel totally free in Udmurt anymore for lack of practice, but still undertakes to come back home for the ceremonies. Some find compromises, in which religion is very present: in 2016 we met the son of an active elder who organises ceremonies in the Tatyshly district. He works in Chernushka and is married to a Russified Udmurt who is Orthodox. They agreed that his wife would bring up their girls in her Christian religion, while the father would bring up their sons in the traditional Udmurt religion. So what about the next generation? While the general tonality of this article is still optimistic, we are afraid that time for optimism is running short...

\section{ACKNOWLEDGEMENTS}

This article was supported by the French grant IUF 2018-2023, Étude interdiscplinaire d'une minorité animiste en Russie d'Europe, les Oudmourtes orientaux : rituels, coutumes, engagement communautaire aujourd'hui, the research grant of the Estonian Literary Museum EKM 8-2/20/3, and by the Centre of Excellence in Estonian Studies (TK 145) through the European Regional Development Fund.

\section{NOTES}

1 In brackets, the percentage of Udmurt language speakers.

2 As an illustration, we may mention the speech of the head of the Tatyshly district, Rushan Garaev, an ethnic Tatar, at the village day in Utar-Elga in June 2016.

3 'Thank you' in Russian. 


\section{SOURCES}

Archive material 1 = National Archives of the Republic of Bashkortostan, F. I-2. Op. 1. D. 1755 . L. 245.

Archive material $2=$ National Archives of the Republic of Bashkortostan, F. I-172. Op. 1. D. 58. L. 64.

Archive material 3 = National Archives of the Republic of Bashkortostan, NA RB. F. I-2. Op. 1. D. 875. L. 1.

Archive material 4 = NOA UIIIaL UdmFITs UrO RAN. Op. 2-N. D. 454. L. 51, 55.

\section{REFERENCES}

Atamanov-Egrapi, Mikhail 2017 [2010]. Proiskhozhdenie udmurtskogo naroda. [Origin of the Udmurt People.] 2nd ed. Izhevsk: Udmurtiia.

Atamanov, Mikhail \& Vladykin, Vladimir 1993. Subetnicheskie ob"edineniia udmurtov. [The Sub-ethnic Groups of the Udmurt.] In: V. Pimenov (ed.) Udmurty: Istorikoetnograficheskie ocherki. [The Udmurt: Historical and Ethnographic Essays.] Izhevsk: Udmurtskii institut istorii, iazyka i literatury UrO RAN, pp. 28-35.

Bernshtam, Tatiana 1990. Khristianizatsiia v etnokul'turnykh protsessakh finno-ugorskikh narodov Evropeiskogo Severa i Povolzhiia (sravnitel'noe obobshchenie). [Evangelisation in the Ethnocultural Processes of the Finno-Ugric Peoples of the European North and the Volga Region (Comparative Generalisation).] In: O. Fishman (ed.) Souremennoe finno-ugrovedenie: Opyt i problemy. [Contemporary Finno-Ugristics: Experience and Problems.] Leningrad: GME, pp. 133-140.

Brennan, James F. 1987. Enlightened Despotism in Russia: The Reign of Elisabeth, 1741-1762. New York: Peter Lang.

Chagin, Georgii 1995. Etnokul'turnaia istoriia Srednego Urala v kontse XVI-pervoi polovine XIX veka. [Ethnocultural History of the Central Urals at the End of the 16th First Half of the 19th Centuries.] Perm: Permskii gosudarstvennyi universitet.

Chernykh, Aleksandr 2017. Udmurty Permi: Istoriia i kul'tura. [The Perm Udmurt: History and Culture.] St. Petersburg: Mamatov.

Davletbaev, Bulat 1986. Teptiari i ikh zemlepol'zovanie. [The Teptyar and Their Use of the Land.] In: I. Gvozdikova \& R. Kuzeev \& H. Usmanov (eds.) Maloizuchennye istochniki po istorii Bashkirii: Sbornik nauchnykh trudov. [Insufficiently Studied Sources about the History of Bashkiriya: Collection of Scientific Texts.] Ufa: BFAN SSSR, pp. 78-158. Available at https://kitaptar.bashkort.org/storage/books/4tlpS rTaQleGAcQtd8U7e5fyq1ymXl6d1HECaSiy.pdf, last accessed on 15 May 2020.

DeWeese, Devin 1980. Religious Affiliation in Their Ethnic Context among the Finno-Ugric Peoples of the Volga-Ural-Region. Ural-Altaische Jahrbücher, Vol. 52, pp. 109-126. Available at https://www.digizeitschriften.de/dms/toc/?PID=PPN856457418_0052, last accessed on 23 April 2020.

Dido 1902. Zametki i nabliudeniia (Iz zametok byvshego sel'skogo uchitelia). [Notes and Observations (From the Notes of a Former Country Schoolteacher).] St. Petersburg: Tipografiia M. Merkusheva. Available at https://istoriki.su/roulette/811-didozametki-i-nablyudeniya-iz-zametok-byvshego-shkolnogo-uchitelya.html, last accessed on 23 April 2020. 
Grishkina, Margarita 1994. Udmurty: Etiudy iz istorii IX-XIX vv. [The Udmurt: Etudes from the 19th-Century History.] Izhevsk: Udmurtiia.

Grishkina, Margarita 1995. Udmurty v sostave Rossiiskogo feodal'nogo gosudarstva (konets XV - pervaia polovina XIX vv.) [The Udmurt within the Russian Feudal State (End of the 15th - First Half of the 19th Centuries).] In: L. Nagovitsin (ed.) Materialy po istorii Udmurtii (s drevneishchikh vremen do serediny XIX $v$ ). [Materials about Udmurtia's History (from the Ancient Times until the Mid-19th Century).] Izhevsk: Izdatel'stvo Udmurtskogo universiteta, pp. 108-138.

Kappeler, Andreas 1982. Russlands erste Nationalitäten. Das Zarenreich und die Völker der Mittleren Wolga vom 16. bis 19. Jahrhundert. Köln \& Wien: Böhlau Verlag.

Kappeler, Andreas 1994. La Russie: empire multiethnique. Paris: Institut d'études slaves. Kel'makov, Valei 1998. Kratkii kurs udmurtskoi dialektologii. [A Brief Course in Udmurt Dialectology.] Izhevsk: Izd-vo Udmurtskogo universiteta.

Kosareva, Irina 2000. Traditsionnaia zhenskaia odezhda periferiinykh grupp udmurtov (kosinskoi, slobodskoi, kukmorskoi, shoshminskoi, zakamskoi) v kontse XIX nachale $X X v$. [The Traditional Female Dress in the Peripheral Udmurt Groups (the Kosa, the Sloboda, the Kukmor, the Shoshma, the Transkama) at the End of the 19th - Beginning of the 20th Century.] Izhevsk: UIIIaL UrO RAN.

Kuzeev, Rail 1992. Narody Srednego Povolzh'ia i Iuzhnogo Urala. Etnogeneticheskii vzgliad na istoriiu. [The Peoples of the Central Volga and the South Urals: An Ethnogenetic Glance at History.] Moscow: Nauka.

Lallukka, Seppo \& Popov, Nikandr 2009. Testing the Limits of the Permissible. Mari Ethno-religious Ferment and Russian Authority, 1820s-1840s. In: Michael Branch (comp. \& ed.) Defining Self: Essays on Emergent Identities in Russia, Seventeenth to Nineteenth Centuries. Studia Fennica, Ethnologica 10. Helsinki: SKS, pp. 316-333.

Lebedeva, Serafima 2008. Удмурт кальк дӥськут / Удмуртская народная одежда / Udmurt Folk Costume. Izhevsk: Udmurtia.

Luppov, Pavel 1999 [1899]. Khristianstvo u votiakov so vremeni pervykh istoricheskikh izvestii o nikh do XIX veka. [Christianity by the Votyak from the First Historic Information about Them to the 19th Century.] Izhevsk: UIIIaL UrO RAN.

Makarov, Leonid 1995. Slaviano-russkoe zaselenie basseina r. Viatki i istoricheskie sud'by udmurtov viatskoi zemli v XII-XVI vv. [The Slavic-Russian Occupation of the Vyatka Basin and the Historical Fate of the Udmurt of the Vyatkaland in the 12th-16th Centuries.] In: L. Nagovitsin (ed.) Materialy po istorii Udmurtii (s drevneishchikh vremen do serediny XIX v). [Materials about the History of Udmurtia (from the Ancient Times until the Middle of the 19th Century).] Izhevsk: Izdatel'stvo Udmurtskogo universiteta, pp. 80-107.

Miropiev, Mikhail 1908. Russko-inorodcheskie shkoly sistemy N.I. Il'minskogo. [The Russian-allogeneic Schools of the Il'minski System.] Zhurnal Ministerstva Narodnogo Prosveshcheniia. [Journal of the Minister of the People's Enlightenment.] Ianvar'. Chast' XIII, novaia seriia, pp. 183-210. Available at https://runivers.ru/upload/iblock/67d/new\%2013.pdf, last accessed on 15 May 2020.

Nasibullin, Rif 1997. Kams'ör udmurt"es. [The Eastern Udmurt.] Invozho, Vol. 2, pp. 11-14. 
Nikitina, Galina 2011. Obshchie svedeniia o zakamskikh udmurtov. [General Data about the Eastern Udmurt.] Authentic Geography. Vyp. 3: Zakamskie udmurty, pp. 3-5. Available at https://issuu.com/soffist85/docs/ag_zakamskie_udmurty, last accessed on 15 May 2020.

Nikitina, Galina 2015. Udmurt Autostereotypes about Physical Beauty (the Late 19th Century). In: Harri Mantila \& Jari Sivonen \& Sisko Brunni \& Kaisa Leinonen \& Santeri Palviainen (eds.) Congressus Duodecimus Internationalis Fenno-Ugristarum, Oulu 2015 Book of Abstracts.Oulu: University of Oulu, pp. 125-126. Available at https://www.oulu.fi/sites/default/files/content/CIFU12BookOfAbstracts_0.pdf, last accessed on 23 April 2020.

Nurieva, Irina 2013. Zakamskie udmurty: traditsiia paradoksov (etnomuzykovedcheskii etiud). [The Eastern Udmurt: The Paradox Tradition (Ethnomusicological Etude).] Etnograficheskoe obozrenie, Vol. 6, pp. 150-158. Available at http://journal.iea. ras.ru/archive/2010s/2013/no6/150.htm, last accessed on 23 April 2020.

Osipov, V.A. 2008. S uvazheniem k proshlomu i otvetstvennost'iu za budushchee. [With Respect towards the Past and Responsibility for the Future.] In: R. Razin \& M. Shishkin (eds.) Udmurty: ocherki o dukhounom ideale, filosofii, drevnikh korniakh, istorii, kul'ture, mentalitete i perspektive sokhraneniia. [The Udmurt: Essays about the Spiritual Ideal, Philosophy, Ancestral Roots, History, Culture, Mentality and Perspective of Preservation.] Izhevsk: KnigoGrad, pp. 17-26. Available at https://elibrary.unatlib.ru/dspace/dsview.html, last accessed on 23 April 2020.

Pesni 2018 = Pesni udmurtov Bavlinskogo raiona Respubliki Tatarstan. [The Songs of the Udmurt of the Bavlinsky District in the Republic of Tatarstan.] Comp. by I.M. Nurieva \& A.P. Kuznetsova \& P.A. Aleksandrov. Kazan: Kazanskaia gosudarstvennaia konservatoriia.

Sadakov, Mikhail 1949. Uchastie udmurtov v krest'ianskoi voine pod rukovodstvom Pugacheva. [Participation of the Udmurt in the Peasants' War Led by Pugachov.] Zapiski, Vyp. 11. Izhevsk: Udmurtgosizdat, pp. 3-33. Available at https://elibrary. unatlib.ru/dspace/dsview.html, last accessed on 23 April 2020.

Sadikov, Ranus 2001. Poseleniia i zhilishcha zakamskikh udmurtov. [Settlements and Housing of the Eastern Udmurt.] Ufa: Gilem. Available at http://tehne.com/ library/sadikov-r-r-poseleniya-i-zhilishcha-zakamskih-udmurtov-materialnyyi-duhovnyy-aspekty-ufa-2001, last accessed on 23 April 2020.

Sadikov, Ranus 2019a. "Prezhde zhe khotia i byli iazychnikami, no nyne magometanskogo veroispovedaniia": k voprosu o priniatii islama zakamskimi udmurtami. [Formerly, We Were Pagans, but Now We Follow the Faith of Islam: To the Issue of Trans-Kama Udmurts.] Voprosy vostokovedeniia [The Problems of Oriental Studies], Vol. 2, No. 84, pp. 32-37.

Sadikov, Ranus 2019b. Traditsionnaia religiia zakamskikh udmurtov (istoriia $i$ souremennost'). [Traditional Religion of the Eastern Udmurt (History and Contemporaneity).] 2-e izd., dop. Ufa: In-t etnologicheskikh issledovanii im. R.G. Kuzeeva UFITs RAN.

Sadikov, Ranus \& Minniyakhmetova, Tatiana 2012. Zarubezhnye issledovateli etnografii, fol'klora i iazyka zakamskikh udmurtov: istoriograficheskii ocherk. [Foreign Scholars of Ethnography, Folklore, and Language by Trans-Kama Udmurts: Essays on Historiography.] Ezhegodnik finno-ugorskikh issledovanii [Yearbook 
of Finno-Ugric Research], Vol. 4, pp. 49-62. Available at http://cyberleninka. ru/article/n/zarubezhnye-issledovateli-etnografii-folklora-i-yazyka-zakamskihudmurtov-istoriograficheskiy-ocherk, last accessed on 24 April 2020.

Safin, Fail \& Mukhtasarova, Elvira \& Khaliulina, Aigul 2019. Etnodemograficheskie i iazykovye problemy udmurtskogo naseleniia $\mathrm{v}$ Bashkortostane. [Ethnodemographic and Linguistic Problems of the Udmurt Population in Bashkortostan.] Vestnik udmurtskogo universiteta [Newsletter of the Udmurt University], Vol. 29, No. 4, pp. 660-668. https://doi.org/10.35634/2412-9534-2019-29-4-660-668.

Torbasov, Oleg n.d. Genotsid kak osnova russkoi gosudarstvennosti. [Genocide as a Basis for Russian Statehood.] Komsomol.narod.ru. Available at http://komsomol.narod. ru/national/Russian_genocide.htm, last accessed on 21 April 2020.

Toulouze, Eva, 2016. Some Ideas about the Continuity and Revitalization in the Udmurt Spring Rituals in Bashkortostan. In: E.A. Iagafova (ed.) Prazdniki i obriady $v$ Uralo-Povolzh'e: traditsii $i$ novatsii $v$ sovremennoi kul'ture. [Festivals and Rituals in the Urals-Volga Region: Tradition and Innovation in Today's Culture.] Collection of articles. Samara: SGSPU, pp. 17-20.

Toulouze, Eva 2017. A Long Great Ethnic Terror in the Volga Region: A War before the War. In: A. Kotljarchuk \& O. Sundström (eds.) Ethnic and Religious Minorities in Stalin's Soviet Union: New Dimensions of Research. Södertörn Academic Studies 72. Huddinge: Södertörn University, pp. 153-172. Available at https://sh.diva-portal. org/smash/get/diva2:1164774/FULLTEXT02.pdf, last accessed on 24 April 2020.

Toulouze, Eva \& Vallikivi, Laur 2016. The Sacred Places of the Bashkortostan Udmurt. Ezhegodnik finno-ugorskikh issledovanii, Vol. 10, No. 3, pp. 146-155. Available at http://finno-ugry.ru/files/1303172918.pdf, last accessed on 24 April 2020.

Zahidullin, Ildus 1997. La conversion à l'orthodoxie des Tatars de la région Volga-Oural aux XVII ${ }^{\mathrm{e}}$-XVIII ${ }^{\mathrm{e}}$ siècles, et ses causes économiques et sociales. In: S. Dudoignon (ed.) L'islam de Russie. Conscience communautaire et autonomie politique chez les Tatars de la Volga et de l'Oural depuis le XVIII ${ }^{e}$ siècle. Paris: Maisonneuve et Larose, pp. 27-64.

Eva Toulouze is a teacher of Finno-Ugric languages and researcher at the Institute of Eastern Languages and Cultures (INALCO - Paris), and a researcher at the Department of Ethnology, University of Tartu, Estonia. Her main fields of interest are the cultures of Russia's Finno-Ugric peoples, the emergence of a written culture in Finno-Ugric areas, and Forest Nenets culture.

evatoulouze@gmail.com

Nikolai Anisimov ( $\mathrm{PhD}$ ) is researcher at the Department of Folkloristics at the Estonian Literary Museum, Estonia, and at the Department of Philological Studies at the Udmurt Institute for Research in History, Language and Literature (UdmFRC UB RAS), Izhevsk, Russia. His main field of interest is Udmurt traditional and contemporary culture, and more precisely, the living ancestors' cult by the Udmurt and their singing tradition.

nikolai.anisimov@folklore.ee 